\title{
Connecting the Different Lexical Category Domains: Cognition in the Zero Derivation of Adjectives from Nouns in Macedonian
}

\author{
Marjana Vaneva, PhD \\ University American College Skopje, \\ School of Foreign Languages, R. Macedonia
}

URL:http://dx.doi.org/10.19044/esj.2019.v15n8p163

\begin{abstract}
Cognition is a basis of cognitive linguistics and a driving force in the noun to adjective zero-derivation. By expanding the meaning of the first lexeme, cognition enables the speaker to derive a new lexeme, and empowers the hearer to understand the semantics of the newly zero-derived element. The paper studies the process of noun to adjective zero-derivation through cognition. It studies the semantic similarity between the same-form lexemes the source and the target lexeme, which belong to different lexical categories, one is a noun and the other is an adjective, in the case when cognition and association links enable the process of zero-derivation to take place. The research method applied here is that Macedonian nouns are taken, compared to Macedonian adjectives with the same form, but similar meaning, when it is exactly the similarity in meaning that is studied, actually, the speaker's and hearer's motivation to zero-derive an adjective from a noun. The conclusion of the paper notes that the morphological identity (derivationally) and the semantic similarity (through cognition), between the two lexemes in Macedonian, can be accompanied by inflectional suffixes for number, definiteness and gender - modifications that can be made to both lexemes. Consequently, the natural-class noun from the left is zero-derived into an adjective on the right, when, in most cases of this kind of zero-derivation, it appears in, what is originally, a two-noun phrase, in which the second remains to be a noun, while the first becomes a zero-derived adjective.
\end{abstract}

Keywords: Noun, Adjective, Zero-derivation, Macedonian.

\section{Introduction}

Zero derivation is a derivational process in which by adding a zero (null) derivational affix to a lexeme from one lexical category or subcategory, a new lexeme is being formed, which belongs to a different category or 
subcategory and therefore has a different distribution and position in the sentence, thus, performs another function; has a similar meaning to the first lexeme, and absolutely the same (derivational) form like the first lexeme, while inflectional modifications and interventions are allowed in favour of the process. This process exists in all languages; yet, it becomes even more common if and when analysed from a cognitive point of view (Vaneva, 2018).

Cognition is a basis of cognitive linguistics and a driving force in the noun to adjective zero-derivation. By expanding the meaning of the first lexeme, cognition enables the speaker to derive a new lexeme, and empowers the hearer to understand the semantics of the newly zero-derived element. As an approach, it is important to be studied because it enables the speaker to comprehend and perceive the world around them, so that it helps for new things to be learnt on the basis of old and already acquired ones. Thus, cognitive approach aids the process of zero derivation through the (semantic) association links that the participants in the conversation make between the old and the new lexeme.

As given by Vaneva (2018: 8), when the way of analysing the meaning of lexical elements is concerned, the traditional model consists of extracting and identifying the meanings of the same lexical element, in which way all meanings of the given lexeme are given the same status. In this case, the lexemes are listed and the zero derivation is observed through the lexemes' formal aspect, when we don't concern ourselves with more detailed analysis of the meaning of lexemes and finding out connection between the source and the target word. Contrary to them, when analyzing the lexical meaning, the structural linguists try to find a common element which will unite all meanings that one lexeme has. But, this is not necessary; actually, it can be even wrong considering the fact that the zero derived element does not carry in itself the semantic domain that the element has had in the source word class.

Due to the fact that there is need for a different and more systematic study of the language notions, cognitive linguistics has been developed as a separate part of the language study. The proponents of this theory claim that the systematic analysis of meaning should be based on the person's cognitive ability, that is, on the ability to perceive the world around us.

As Saeed (1997: 299) says, the linguistic knowledge is part of the general cognition. The cognitive linguists emphasise the difference between the formal and the functional approach to the language. The first, to which the generative grammar belongs, is often connected with the understanding that knowledge of linguistic structures and rules forms an autonomous module, independent of the other mental processes for attention, memory and thinking. In that aspect, the study of linguistic semantics blurs the difference between the language knowledge and the encyclopedic knowledge from real life. As far as the second - functional - approach is concerned, which is maintained by 
the cognitive linguists, differentiating linguistic levels of analysis harms our language perceptions, since never can syntax be independent of semantics and pragmatics.

In the cognitive-linguistic literature, the meaning is based on the conventional concept structures. In this way, the semantic structure is formed to show the mental categories which people create on the basis of their behaviour and world experience. The cognitive linguists agree with the suggestion that Lakoff and Johnson (1980) make, that metaphor is the basic element in our categorization of the world as well as in the reflective processes. Thus, in cognitive linguistics, the metaphor is considered to be a basic instrument for semantic expansion of the word, that is, it maps the meaning of one lexical element from one domain into another, when the meanings that superficially seem not to be able to be connected, but the speaker regards as close and possible to be connected, are practically connected indeed.

Other authors are Flavell, Miller, Miller (2002: 5-26), who think that cognition embraces two parallel and complementary aspects which are called assimilation and accommodation. The first refers to adapting the stimulations from outside to one's own inner mental structures, while accommodation is an opposite or complementary process - a process of adapting the mental structures to the outer stimulations structures. This system does not only make a mental copy of what has been experienced, but with assimilation the outer data is being interpreted and constructed with regards to the person's existing cognitive system; whereas with accommodation, the cognitive system is minimally changed to explain the outer data structure. In this continuous trial to adapt and assimilate the new, previously unassimilated elements from the surroundings, cognitive development occurs.

Nonetheless, this special branch of linguistics - cognitive linguistics has its own, special approach to language, and the language development is based on one's power to perceive, while people perceive by finding similarities of the new elements with the respective prototype of the given category. This shows that the inner structure of the word meaning is not autonomous and unique but it depends on our general stand on the world, whereas the word meaning is analysed on the basis of similarity with the prototype; more precisely, with the natural class of the lexeme.

In the English literature, several authors that have defined zero derivation and its manifestation in the language will be mentioned. Namely, Adams (1973: 16) talks about 'full' and 'partial' zero derivation, when she says that full zero derivation is a derivational process that plays an important role in several word formation models, while the partial type of the process is of syntactic type. This is so because when a word zero derives into another, a new word is being formed, while the partial type of the process happens when 
the new lexeme accepts only some of the characteristics of the new lexical category.

Hurford and Heasley (1983: 206) maintain that when analysing the derivation or formation processes, we ought to take into consideration that it is not one, but three processes:

1. Morphological - changing the form of the word by adding a prefix or a suffix;

2. Syntactic - changing the type of word; like in our case, which is subject to analysis in this paper, from noun to adjective;

3. Semantic - deriving or creating new meaning.

Plag (2003: 12) states that zero derivation forms words from others without clear marking, which does exist, but isn't visible, and it would be wrong to name it a zero morph, because what is zero is the outer expression, not the meaning.

Laurie Bauer and Salvador Valera (2005) define zero derivation, if every change of category without affixation is undoubtedly zero derivation, and how to determine the direction of zero derivation.

Manova and Dressler in Bauer and Valera 2005: 138-139 make the difference between morphological and syntactic zero derivation, saying that in the first type, the target lexeme takes the inflection of the new word class to which it is zero derived, while in the second type, the original inflection is kept and what changes is only the syntactic role of the changing element, but no morphological changes happen.

In the Macedonian literature, there is no author who explicitly talks about zero derivation, but there are studies which treat the conversion of the lexeme from one lexical category or subcategory to another, when using no overt affix, that is, by using a zero derivational affix. This proves that the process does exist in Macedonian, but it is not studied enough or not paid sufficient scientific attention. However, it is definitely not seen through the prism of cognitive research (Vaneva 2018). But, authors who do write about change in category, are B. Koneski, (1967), Zh. Cvetkovski, (1990), S. Veleva (1994). As far as our direction: noun to adjective is concerned, the following authors will be mentioned:

K. Koneski (1987: 51-60) says that the main characteristic which is in the basis of the derivation is the connection between the words which belong to the different lexical categories, having the source word on one side and the target lexeme as a result of the process on the other side. This same author (1995: 19) is among the first in the science of the Macedonian language, who uses the so-called zero morph, explaining that to the zero derivational basis a derivational zero affix and an inflectional suffix are added, so that at the end of the process a new lexeme is formed as a product of the process of zero derivation. 
Z. Topolinjska (1998: 65-69) talks about syntactic derivation of nouns and noun phrases when from attributively used adjectives nouns are zero derived which is a reversal process to the one which is of our interest. However, this is the closest to what we analyse since the direction is different, but at least the same lexical categories are studied - nouns and verbs.

What our paper exemplifies are lexemes taken from Macedonian dictionaries and Macedonian grammar books, such as, ruček $\mathrm{n} . \rightarrow$ ruček adj.: ubav ruček $\mathrm{n}$. (nice lunch) $\rightarrow$ ruček vreme adj. (lunch time), when the noun ruček (lunch) names the meal and, by following the cognitive path in the semantic expansion, on the other side of the process, we are taken to the sameform lexeme, but this time an adjective that modifies the noun which follows, and describes the kind of noun. It is this second, adjectival, lexeme that is a result of the zero-derivational process. The analysis is conducted in such a way that Macedonian nouns are taken, and they are compared to Macedonian adjectives with the same form, but similar meaning, when it is exactly the similarity in meaning that is studied, actually, the speaker's and hearer's motivation, in its basis - cognition, to zero-derive an adjective from a noun. In all the examples, the starting lexeme is simply taken from Macedonian dictionaries (Rečnik na makedonskiot jazik so srpskohrvatski tolkuvanja, 1994, and Tolkoven rečnik na makedonskiot jazik, 2003) as well as from grammar books (Gramatika na makedonskiot literaturen jazik, 1967, and Zboroobrazuvanjeto vo sovremeniot makedonski jazik, 1995) compared to its zero derived element in all the aspects of the process, with the whole example (phrase or sentence) being constructed by the author. The English translation of the Macedonian examples, supplied for the pure purpose of enabling the non-speakers of Macedonian to understand the process, is also made by the author.

\section{Analysis and results}

One of the prototypical types of zero-derivation in Macedonian, which displays formal overlapping, semantic expansion, and lexical category difference is the noun to adjective direction, that is, the type which zero derives adjectives from nouns. This paper will analyse masculine and feminine nouns, for which the following formula is valid:

\section{L1 N (=MB+ØDS $) \rightarrow$ L2 Adj. (=MB+ØDS $)^{9}$}

All the (Macedonian) examples given in this paper are taken from Macedonian dictionaries and grammar books, and each Macedonian example subject to

\footnotetext{
9 The elements of the scheme stand for the following: L1 - lexeme $1, \mathrm{~N}$ - noun, MB -
} motivating base, $\varnothing$ - zero, DS - derivational suffix, L2 - lexeme 2, Adj. - adjective. 
analysis is listed first in the pair, while in order for that Macedonian example to be understood by non-speakers of Macedonian, each example's translation in English is given below, in square brackets.

\section{Zero derivation from a masculine noun to adjective}

1.1 Zero derived adjectives from nouns of this type that determine the material from which the noun is made within the adjective-noun structure on the right are the following:

kamen $\rightarrow$ kamen: most napraven od kamen $\rightarrow$ kamen most

[stone $\rightarrow$ stone: a bridge made of stone $\rightarrow$ a stone bridge]

plamen $\rightarrow$ plamen: Kuќata e vo plamen. $\rightarrow$ plamen stolb

[flame $\rightarrow$ flame: The house is in flame. $\rightarrow$ flame pillar]

jačmen $\rightarrow$ jačmen: leb od jačmen $\rightarrow$ jačmen leb

[rye $\rightarrow$ rye: bread made of rye $\rightarrow$ rye bread]

The example with kamen (stone) shows that the noun stands for the object, and when it changes its natural class, like in the example with the other two lexemes, the adjectival lexeme denotes the material from which the object is made. In the first example, we start with the noun kamen (stone) that names the material and in the speaker's mind it can be very easily zero derived into an adjective, again referring to what the noun is made of, which is actually the basis for semantic-metaphorical expansion.

Very similar to the previously listed examples are also the ones in continuation, which when used as zero derived adjectives, except for the material, also determine the type from which the adjective is made:

šik $\rightarrow$ šik: tuka se prodava šik $\rightarrow$ imaat šik garderoba

[chic $\rightarrow$ chic: they sell chic here $\rightarrow$ they have got chic clothes]

kremen $\rightarrow$ kremen: zdrav kako kremen $\rightarrow$ kremen dzid

[quartz $\rightarrow$ quartz: as healthy as quartz (literal translation) $\rightarrow$ quartz wall]

šimšir $\rightarrow$ šimšir: vo dvorot imaat šimšir $\rightarrow$ otvorija šimšir-porti

[boxwood $\rightarrow$ boxwood: they have got boxwood in their yard $\rightarrow$ they opened boxwood gates]

In the first of the given examples, the noun šik (modern) is for something modern, while the zero derived adjective, through metaphorization, modifies the noun garderoba (clothes) like something modern. It is the same 
situation in the other two examples where the semantic feature is kept, but a new lexeme is produced, which receives a different syntactic role in the sentence due to the different distribution in the surrounding context.

Certainly, in all these cases the noun is given in its basic dictionary form and it totally overlaps with the adjectival form, and both the noun and the adjective can easily take the inflectional suffixes for number, definiteness, and for gender too, according to which ending the noun dictates and chooses the zero derived adjective. Namely, both lexemes, as different parts of speech, take inflections for definiteness, but that inflection results from the realization of the lexeme in the language and it does not mean that with its help we create conditions for zero derivation. On the other hand, the semantic aspect requirement is met by transferring the characteristic that the noun has onto the adjective, and what the latter does with the metaphorically created and acquired feature is keep it on itself and with it modify the noun that is in its scope of activity.

More examples are given in continuation, which in the productive, creative word formation, and in the part of zero derivation illustrate the use of nouns as adjectives when two nouns are placed next to each other. Thus, the second remains to be the centre of the noun phrase, while the first gets a function of a modifier and is in this way zero derived to a new, adjectival lexeme. In such a case, the attention is drawn to the zero derived element because it is exactly the adjective on which the type of the next element depends - the noun to which the zero derived adjective gives a characteristic:

ruček $\rightarrow$ ruček: Ručekot e gotov. $\rightarrow$ ruček vreme

[lunch $\rightarrow$ lunch: The lunch is ready. $\rightarrow$ lunch time]

dzver $\rightarrow$ dzver: golem dzver $\rightarrow$ dzver čovek

[dragon $\rightarrow$ dragon: a big dragon $\rightarrow$ a dragon man]

sladoled $\rightarrow$ sladoled: ovošen sladoled $\rightarrow$ sladoled torta

[ice cream $\rightarrow$ ice cream: fruit ice cream $\rightarrow$ ice cream cake]

poet $\rightarrow$ poet: golem poet $\rightarrow$ poet revolucioner

[poet $\rightarrow$ poet: a big poet $\rightarrow$ a poet revolutionary]

lekar $\rightarrow$ lekar: mlad lekar $\rightarrow$ lekar specijalist

[doctor $\rightarrow$ doctor: a young doctor $\rightarrow$ a doctor specialist]

The meaning transfer and the function change will be described only with the last example, and this explanation will be very similar to the remaining cases. Namely, what is easily noticeable is that the noun lekar 
(doctor) stands before another noun and modifies it giving to it characteristics which it contains for naming the object. On the left, the noun is part of a sentence, while on the right, as a derived adjective, it precedes the noun in the new adjective-noun structure.

From semantic and metaphorical aspect, the understanding of this zero derived noun-adjective structure depends on the cognitive ability of the participants in the conversation, because the speaker starts with the features of the word lekar (doctor), and that is a person who is a specialist, but a doctor specialist, specialist in the medical science, not another kind of specialist. Therefore, we see the function (and the power) of the first element in this twoelement structure to define and specify the second element. These characteristics are transferred onto the other element - човек (man), which is not a subject to analysis of zero derivation, but it is an element with a function of an object, since it is exactly the existence of that noun that not only does it not allow, but it even imposes lexical and syntactic change of the element before it. The following scheme portrays these explanations:

masculine noun

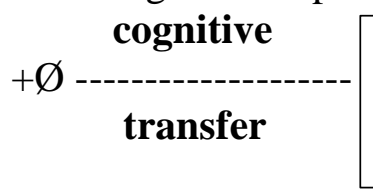

material, type, characteristic

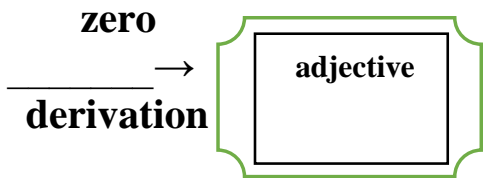

Scheme 1: Zero derivation from a masculine noun to an adjective in Macedonian

\section{Zero derivation from a feminine noun to adjective}

The same derivational-syntactic process also occurs in the next examples, where the only difference between the previous and this subgroup is in the fact that in this case a feminine noun starts the zero derivation. Of course, now, in the adjective-noun structure a more important place is taken by the zero derived element, which, with the new function, modifies the unconverted noun.

2.1 Let us consider the examples in continuation:

sila $\rightarrow$ sila: Treba da upotrebiš sila. $\rightarrow$ sila rabota

[strength $\rightarrow$ strength: You should use strength. $\rightarrow$ a strength thing]

uzina $\rightarrow$ uzina: sluzat uzina vo 5 popladne $\rightarrow$ uzina vreme

[snack $\rightarrow$ snack: they serve snack at 5 p.m. $\rightarrow$ snack time]

harmonika $\rightarrow$ harmonika: Toj sviri harmonika. $\rightarrow$ harmonika vrata [harmonica $\rightarrow$ harmonica: He plays harmonica. $\rightarrow$ harmonica door]

budala $\rightarrow$ budala: Ne bidi budala! $\rightarrow$ budala narod

[fool $\rightarrow$ fool: Don't be a fool! $\rightarrow$ foolish people] 
selanka $\rightarrow$ selanka: vredna selanka $\rightarrow$ selanka zena

[peasantwoman $\rightarrow$ peasantwoman: $a$ hard-working peasantwoman $\rightarrow a$ peasantwoman]

saksija $\rightarrow$ saksija: edna saksija $\rightarrow$ saksija cveḱe

[pot $\rightarrow$ pot: one pot $\rightarrow$ flower pot]

When we say saksija (pot), we mean the container in which flowers are planted, thus this zero derived adjective describes the flowers as such in $a$ flower pot, and not in the garden, or let alone, picked in a bouquet. Certainly, from a morphological aspect, the zero derived adjective can take the inflections for definiteness and for plural within the adjective-noun phrase, and can be distinguished from the words before the examples, but only in terms of the inflectional affixes which are their grammatical realisations.

2.2 In continuation, we will give feminine nouns that end in -ачка, -ичка, from which adjectives with the same form and meaning are derived. Within the adjective-noun structure, the adjective can have two functions: to determine the character of the noun and to determine its belonging. The first function of the derived adjective is illustrated with the examples in continuation:

kosačka: se bara kosačka $\rightarrow$ kosačka mašina

[a female mower is wanted $\rightarrow$ a mowing machine]

patnička: edna patnička $\rightarrow$ patnička torba

[one female passenger $\rightarrow$ a passenger's bag]

posrednička: stranska posrednička $\rightarrow$ posrednička misija

[a foreign female intermediary $\rightarrow$ intermediary mission]

plivačka: naša plivačka $\rightarrow$ plivačka pateka

[our female swimmer $\rightarrow$ a swimmer's lane]

šivačka: se bara šivačka $\rightarrow$ šivačka igla

[a needlewoman is wanted $\rightarrow$ a sewing needle]

Here, what is shown is the type and the nature of the noun in question, more precisely, it is said that the machine is for mowing, the bag is for travelling, the mission is of intermediary character, the track is for swimming and the needle is for sewing. 
The examples in continuation confirm that the object in question which comes after the adjective in the expression on the right side belongs to the noun given in the sentence on the left, with which the process of zero derivation in this group starts. Otherwise, this subgroup has an abundance of examples considering that there is a perfect overlapping of the noun form with the one of the adjective, and there are no semantic limitations, while the meaning of the noun is fully transferred to the adjective. Part of these are the following:

naslednička: naslednička na stan $\rightarrow$ naslednička izjava [a flat heiress $\rightarrow$ an heiress' statement]

katolička: Taa e katolička. $\rightarrow$ katolička kuḱa [She is a Catholic. $\rightarrow$ a Catholic house]

učenička: odlična učenička $\rightarrow$ učenička kniška [an excellent female pupil $\rightarrow$ a pupil's index book]

nastavnička: nastavnička po jazik $\rightarrow$ nastavnička kancelarija [a female language teacher $\rightarrow$ a teacher's office]

zarobenička: nova zarobenička $\rightarrow$ zarobenička košula [a new female prisoner $\rightarrow$ a prisoner's shirt]

In these examples, the noun that follows the zero derived adjective in the structure on the right belongs to the noun on the left from which the derived element is formed. Thus, the statement belongs to the heiress, the house to the Catholic, the index book to the student, the office to the teacher, and the shirt to the prisoner.

As far as the form of the lexemes in the analysed structures is concerned, on the left side there is a feminine noun, accompanied by a verb or adjective and can take inflections for definiteness, according to the requirements of the surrounding elements. On the other side, in the structure on the right, our zero derived adjective from noun is given, which isn't inflected for definiteness here, but it can be, and also a noun is given, whose modifier is the zero derived element.

On the other hand, when the metaphorical transfer is in question, it is performed in a very simple and obvious way with meaning which shows that the zero derived adjective in the new structure points that the noun on the right belongs to the source element that has a role of a noun on the left, and of an adjective on the right. The meaning basis is again maintained, so that from 
naming the people, the speaker's cognition makes us come to an adjective word which will determine the belonging of the notion.

Yet, what can't be seen from the examples but is understood when observing only the target lexeme - the adjective, is that it actually doesn't mean that the owner of the noun is necessarily of feminine gender, but owners can be also people of masculine gender since the nouns of feminine and masculine gender have mutually different forms, due to which the noun of feminine, not the one of masculine gender, has the same form as the adjective. In continuation let us see the formal difference between the masculine noun and the adjective:

naslednik - naslednička izjava

[heir - an heir's statement]

katolik - katolička kuḱa

[Catholic - a Catholic house]

učenik-učenička kniška

[student - a student's index]

nastavnik - nastavnička kancelarija

[teacher - a teacher's office]

zarobenik - zarobenička košula

[prisoner - a prisoner's shirt]

This illustrates that it cannot be that a masculine noun is used as a starting point when zero deriving an adjective, but in the derived element the masculine gender referent is embodied, so that in the first example the noun izjava (statement) could have been given by a female - naslednička (heiress) or a male - naslednik (heir). According to this, the plural of the adjective naslednički (heirs') will refer to more people, that is, naslednici (heirs), regardless of the fact whether they are of masculine or feminine gender, but it can also be formed from a feminine noun:

eden naslednik - naslednička izjava

[an heir - an heir's statement]

edna naslednička - naslednička izjava

[an heiress - an heiress's statement] 
dve naslednički-naslednički izjavi

[two heiresses - heiresses' statements]

trojca naslednici - naslednički izjavi

[three heirs - heirs' statements]

This means that besides the fact that it can accept affixes for definiteness (nasledničkata izjava - an heiress's statement), the zero derived adjective can also take a plural form so that the feminine noun in plural has the same form as the adjective in plural, whereas there is formal discrepancy between the masculine noun in plural and the plural form of the adjective, because the plural of these masculine nouns, mainly, has forms in - $и$, like: косачи (mowers), nатници (travellers), ученици (students), etc., but therefore, the adjectival form is the same as the adjective derived from feminine nouns. Simply, the feminine nouns that end in -ачка, -ичка, in plural have an -ички ending and thus have a same form with the masculine noun in singular and plural, but also with a plural adjective, regardless of its gender.

In this subtype, as well as in any other, the semantic aspect of zero derivation is satisfied with the meaning transfer from an old to a new variant, and by bridging the known and the unknown for the purpose of zero deriving another lexeme. Absolutely the same meaning is maintained when going from one to another word, while the form of the two lexemes is totally identical so that the source lexeme - the noun - without obstructions belongs to the other word group - the adjective, thus illustrating the clear, prototypical type of zero derivation.
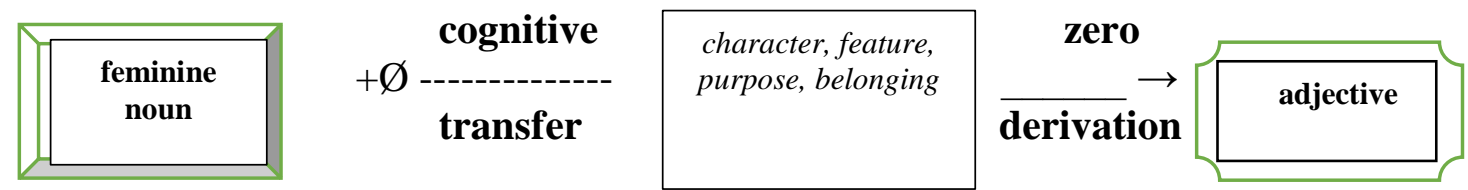

Scheme 2: Zero derivation of an adjective from a feminine noun in Macedonian

\section{Conclusion}

In the Macedonian word formation process, the production of an adjective from a masculine and feminine noun is clear zero derivation, when the lexeme does not change morphologically, neither in the one, nor in the other example.

The masculine nouns that we have chosen end in a consonant and achieve a total overlapping with the target, derived adjectival lexeme, when from naming the material, specifying the form, the quality and the inner characteristic of the named notion and object, an adjective is formed. It is the same case with the feminine nouns that end in a vowel and formally overlap with the target adjectival lexeme, whereby along with being clear, in Macedonian this process is full, when the derived element takes the suffixes 
for number and definiteness. In Macedonian, there is a kind of zero derivation of a feminine noun to an adjective only when the feminine noun creates conditions for the process to be analysed, and that does not happen with the masculine and neuter nouns since their form does not overlap with the adjectival one. Thus, only when the noun is of feminine gender, a zero derived adjective is formed, because both the starting lexeme - noun - and the adjective as a target element have an - ачка or -ичка ending. In Macedonian, this kind of change enables the newly derived adjective to be fully changed and to take suffixes for plural and definiteness.

In this Slavic language, the starting noun lexeme can be both in singular and plural, depending on the context when the adjective can also take the characteristics for number; in singular - masculine and feminine gender: eden poet $\rightarrow$ poet revolucioner [one poet $\rightarrow$ poet revolutionary], vredna selanka $\rightarrow$ selanka žena [a hard-working peasant woman $\rightarrow$ a peasant woman], as well as in plural - of masculine and feminine gender: dvajca poeti $\rightarrow$ poeti revolucioneri [two poets $\rightarrow$ poets revolutionaries], vredni selanki $\rightarrow$ selanki ženi [hard-working peasant women $\rightarrow$ peasant women]. As a matter of fact, the masculine and feminine nouns, zero derived to adjectives, manage to achieve a total formal identity, and in the new structure they modify the noun by means of the zero derived adjective. Otherwise, when zero deriving from a feminine noun to an adjective, the noun has to be of feminine gender so that it has a same form with the adjective: naša plivačka $\rightarrow$ plivačka pateka [our female swimmer $\rightarrow$ a swimmer's lane]. In this case, the plural of the noun is equally possible, which will overlap with the plural of the adjective, the same for all three genders: dve plivački $\rightarrow$ plivački klub [two female swimmers $\rightarrow$ a swimmers' club]. As far as the cognitive transfer is concerned, the speaker finds the connection between the noun and the object, when the latter belongs to the noun or to the person that is modified by the characteristic instilled in the new adjectival element.

\section{References:}

1. Adams, V. (1973). An introduction to Modern English wordformation. London: Longman.

2. Bauer, L., \& Salvador, V. (2005). Approaches to conversion / zeroderivation. Münster: Waxmann Publishing Co.

3. Cvetkovski, Zh. (1990). "Prilog kon sintaksata na prilozite". In Godišen zbornik: annuaire, kniga 16. Skopje: Filološki fakultet na Univerzitetot, 183-185.

4. Flavell, J.H., P.H. Miller, \& Miller, S.A. (2002). Cognitive Development. Fourth edition, Prentice Hall.

5. Hurford, J.R., \& Heasley, B. (1983). Semantics: a coursebook. Cambridge: Cambridge University Press. 
6. Koneski, B. (1967). Gramatika na makedonskiot literaturen jazik; del I and II. Skopje: Kultura.

7. Koneski, B. (Ed.). (1994). Rečnik na makedonskiot jazik so srpskohrvatski tolkuvanja. Tom: I, II, III; Skopje: Detska radost.

8. Koneski, K. (1987). "Od problematikata na zboroobrazuvanjeto na glagolite vo makedonskiot jazik”. In Predavanja na XIX Seminar za makedonski jazik, literatura i kultura; Skopje and Ohrid, 8-28. VIII 1986, Univerzitet “Kiril i Metodij”. Skopje: Seminar za makedonski jazik, literatura i kultura, 51-61.

9. Koneski, K. (1995). Zboroobrazuvanjeto vo sovremeniot makedonski jazik. Skopje: Bona.

10. Lakoff, G., \& Johnson, M. (1980). Metaphors We Live By. Chicago: University of Chicago Press.

11. Plag, I. (2003). Word-formation in English. Cambridge: Cambridge University Press.

12. Saeed, J.I. (1997). Semantics. Oxford: Blackwell Publishers Ltd.

13. Topolinjska, Z. (1998) "Za eden interesen mehanizam na supstantivizacija”. In Prilozi: Contributions XXIII 1-2. Skopje: Makedonska akademija na naukite i umetnostite, Oddelenie za lingvistika I literaturna nauka, 65-69.

14. Vaneva, M. (2018). "Cognitive Mapping of the Noun Domains When Zero-deriving Proper from Common Nouns in Macedonian", International Journal of Multidisciplinary and Current Research, Vol. $6,8-13$, US.

15. Veleva, S. (1994). Zboroobrazuvanjeto vo poezijata na Gane Todorovski - magisterski trud, Univerzitet "Sveti Kiril I Metodij”. Skopje: Filološki fakultet.

16. Velkovska, S. (Ed.). (2003). Tolkoven rečnik na makedonskiot jazik; tom I, II, III. Skopje: Institut za makedonski jazik “Krste Misirkov”. 